\section{Piotr Roszak}

Uniwersytet Mikołaja Kopernika

Uniwersytet Nawarry

piotrroszak@umk.pl

DOI: http://dx.doi.org/10.12775/BPTh.2016.024

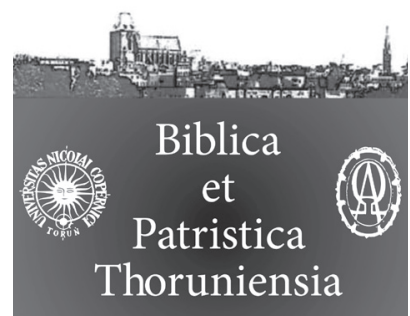

9 (2016) 3: 119-132

ISSN (print) 1689-5150

ISSN (online) 2450-7059

\title{
Tomizm biblijny: metoda i perspektywy
}

\section{Biblical Thomism: Methods and Perspectives}

\begin{abstract}
Streszczenie. Rozwijający się w ostatnich latach tzw. tomizm biblijny stanowi projekt odzyskania biblijnego wymiaru teologii Akwinaty, a przez to inicjuje szereg kwestii dotyczących metody teologicznej. Odkrywane i tłumaczone na wiele języków komentarze biblijne Tomasza, choć w większości czekające na wydanie krytyczne, stawiają badaczy przed pytaniami dotyczącymi relacji dzieł systematycznych i skrypturystycznych. Tomizm biblijny akcentuje cyrkulację między Biblią a teologią spekulatywną, ale także powiązania między dogmatem a nauką moralną, czego czytelnym przykładem jest podejmowane w artykule rozumienie simplicitas według Akwinaty, które wychodzi od natury Boga i kształtuje postawę prostoty moralnej (prostoty serca) u człowieka.
\end{abstract}

Abstract. Biblical Thomism which has developed in the recent years constitutes a project of recovering a biblical dimension of Aquinas's theology and, as a result, initiates a number of questions concerning a theological method. Although the majority of Thomas's biblical commentaries are still awaiting a critical study they have been discovered and translated into many languages confronting the researchers with the questions on the relation between systematic and scripturalist works. Biblical Thomism accentuates the circulation between the Bible and speculative theology and the relations between dogma and moral teaching, a clear example of which is the understanding of simplicitas undertaken in this article. According to Aquinas, it stems from the nature of God and shapes the attitude of moral simplicity (the simplicity of the human heart).

Słowa kluczowe: egzegeza średniowieczna; auctoritas; prostota Boga; sens dosłowny; Tomasz z Akwinu.

Keywords: medieval exegesis; auctoritas; simplicity of God; literal sense; Thomas Aquinas. 
Dosoborowej odnowie tomizmu i jego przyszłości poświęcono już wiele uwa1 gi w minionych latach. Cenne opisy odnajdziemy u DiNoia OP ${ }^{1}$, J. Haldane'a ${ }^{2}$ czy S.-Th. Bonino OP ${ }^{3}$, w których pytają, co to znaczy być dziś tomistą, zwłaszcza w kontekście post-sekularnym i przedłużającej się ponowoczesności, która jak każde post- przede wszystkim zapowiada coś nowego, co wykuwa się w nawiązaniu do poprzedniej myśli ${ }^{4}$. W okresie ideowego „przejścia” również na początku XXI wieku Akwinata, jak pokazują badania prof. Enrique Alar$\operatorname{cona}^{5} \mathrm{z}$ Uniwersytetu Nawarry, odgrywa swoją ważną rolę, potwierdzoną niespotykanym wcześniej wzrostem publikacji na jego temat, w których dostrzega się atrakcyjność wypracowanego pojęcia „teologii” jako sacra doctrina oraz że dokonało się rozróżnienie na teologię spekulatywną i opartą na objawieniu biblijnym (narracji ewangelicznej), ale w pełni zintegrowanych. Tomasz z Akwinu jest tym, jak zauważa G. Dahan, który znajduje się w końcowej fazie tego procesu różnicowania się obu „teologii” albo mówiąc inaczej to on dokonuje ostatecznego ich powiązania pomimo odmienności perspektyw i to w chwili, gdy zapewne wielu jemu współczesnym wydawało się, że te drogi całkowicie się rozejdą i stworzą światy alternatywne ${ }^{6}$.

Tomasz był bez wątpienia świadkiem epoki, która przechodziła od narracji właściwej dla teologii monastycznej, opartej na lectio divina, do jego scholastycznej wersji, wykorzystującej narzędzia ludzkiej myśli, którą stawia się w służbie Objawienia i znajdującej swój wyraz w artykułowaniu quaestio ${ }^{7}$. Teologia, o której myślał Akwinata, to twórcze napięcie myśli, która nie jest podatna na „Zamrażanie” intelektualnego namysłu nad Objawieniem, ale wpisywanie go w odpowiednie ramy, które nie krępują, ale są żyznym środowiskiem (coś co odpowiada łac. humus, jak to już zauważał swego czasu Henri de Lubac) pogłębionej refleksji. To pokazuje, dlaczego w Tomaszowej egzegezie jest tak

\footnotetext{
1 Por. J.A. DiNoia OP, Thomism After Thomism, s. 231-245.

2 J. Haldane, Thomism and the Future, s. 158-169.

3 S.Th. Bonino, To be a thomist, s. 765.

4 T. Rowland, Culture and the Thomist.

5 Obserwowany wzrost publikacji nt. myśli Tomasza pod koniec XX wieku i na początku nowego stulecia jest zdecydowanie większy niż po Aeterni Patris, choć to właśnie ta encyklika utrwaliła się w świadomości jako „kamień”, który ściągnął lawinę badań nad Tomaszem. To jednak „Fides et ratio” okazuje się z pewnej perspektywy silniejszą inspiracją do badań, w które obfituje współczesna literatura filozoficzna. Por. E. Alarcón, El tomismo contemporáneo, s. 25-32.
}

6 G. Dahan, Thomas Aquinas: Exegesis, s. 45.

7 Ph. Rosemann, What is an Author?, s. 35-64. 
wiele miejsca na metafizykę ${ }^{8}$, która nie zasłania przekazu biblijnego, ale go eksplikuje. Już św. Hieronim zwracał uwagę, że Ewangelia polega nie na słowach Pisma, ale na jego znaczeniu, „nie [kryje się] w liściach słów, ale w korzeniu rozumienia"'.

Pośród wielu prób zmierzenia się z tym dziedzictwem Tomasza, wydaje się interesująca szczególnie jedna odmiana tomizmu, która nieśmiało toruje sobie drogę ostatnimi czasy i została nazwana mianem tomizmu biblijnego. Jej zalążki odnajdujemy w pismach S.Th. Pinckaersa OP, twórczo kontynuowane przez M. Leveringa i przynoszące owoce w wielu publikacjach dotyczących szczegółowych zagadnień z zakresu doktryny moralnej Akwinaty ${ }^{10}$. Nie chodzi w tym jednak o czyste „materialne” odzyskiwanie kolejnego segmentu dzieł Akwinaty, ale dotarcie do metody uprawiania sacra doctrina, w której biblijne zakorzenienie okazuje się kluczowe ${ }^{11}$. Nie jest to apoteoza egzegezy, ale wpisanie jej w proces teologicznego namysłu, który nie może być jej pozbawiony i pozostaje $\mathrm{w}$ istotnym napięciu. Swego czasu von Balthasar zauważał, że współczesna mu egzegeza liberalna paradoksalnie utrudnia dostęp do Jezusa, tak jak w czasach Zbawiciela tłum Go otaczający, ale i uczeni w Piśmie, egzegeci Starego Prawa, stanowili kordon nie do przejścia (nawet dla Maryi i Jego bliskich). Wedle bazylejskiego teologa dziś taki kordon intelektualny przeszkadza w dostępie do Jezusa (choć optymistycznie zauważa, że ludzie prości mają swoje sposoby, aby jednak dotrzeć do Zbawiciela), a pozostając w klimacie tego obrazu wydaje się, że właśnie tomizm biblijny jest szansą na przerwanie tego trzymającego w kleszczach teologicznego uścisku, zapatrzenia w siebie i spierania się o szczegóły, bez uwzględniania wizji całości. To wyjście z sytuacji, w której bibliści nie uprawiają teologii, deprecjonując pozakrypturystyczny kontekst poznawczy, a teologowie budują swoje syntezy w abstrahowaniu od Biblii. Istnieje potrzeba uwzględniania „obu ksiąg”, którymi żyli średniowieczni egzegeci i potrafili zbudować syntezę: księgi natury i księgi Pisma. Nie może dziwić zatem, dlaczego rozwój nauk „świeckich” szedł w parze z rozwojem studiów biblijnych: było

8 M. Levering, Pismo Święte i metafizyka. Warto podkreślić na kluczową rolę „kontemplacji” w praktyce teologicznej, ku której prowadzi również chrześcijańska egzegeza biblijna (tak podkreślana przez Wiktorynów, zwłaszcza Hugona od św. Wiktora choćby w Didascaliconie). Por. także mój komentarz do propozycji Leveringa: P. Roszak, Exégesis y metafísica, s. 301-323.

9 Por. A. Canellis, Jerome's hermeneutics, s. 49-76.

10 Za prekursora tomizmu biblijnego uchodzi S.Th. Pinckaers, choć najważniejszym przedstawicielem nurtu, początkowo określającego się jako Ressourcement Thomism, jest dziś Matthew Levering. Por. J. Berkman, C. Steven Titus (eds.), The Pinckaers Reader; por. także R. Hütter, M. Levering (eds.), Ressourcement thomism.

11 P. Roszak, Biblia i metafizyka, s. 9-21. 
to specyficzne sprzężenie zwrotne, które dostrzegało potrzebę studium świata, gramatyki dla lepszego rozumienia Pisma, ale także wyrażało się tu przekonanie o ich zależności z racji tego samego Stwórcy. Nie chodzi jednak o rekonstruowanie dawnych praktyk i zapominanie o tym, co wniosły wieki rozwoju egzegezy od czasów św. Tomasza do naszych, ale zwrócenie uwagi na struktury nośne tej praktyki teologii, która nigdy się nie starzeje.

\section{1. «Tomizm biblijny» a strategia argumentacyjna Akwinaty na podstawie auctoritas}

Tomaszowe podejście do autorytetów w myśleniu teologicznym zwraca współcześnie coraz większą uwagę badaczy, gdyż ukazuje jego - i całej scholastyki jego czasu - pomysł na sacra doctrina, czyniący z tak rozumianej teologii „łącze" pozostające w życiodajnym kontakcie $\mathrm{z}$ innymi gałęziami wiedzy. Teologia nie była królową, która wyizolowana od reszty snuje refleksje ponad głowami, lecz była tą, która „podporządkowuje” inne dyskursy, włącza w budowane pytania dotychczas przywoływane autorytety. Sięgająca Piotra Abelarda próba krytycznego podejścia do autorytetu znajduje u Akwinaty wzorzec pełen równowagi: to nie zakładanie negatywnej roli autorytetu ani sięganie po niego w każdy możliwy sposób, aby zamknąć dyskusję. To nie pasja ukazywania sprzeczności między nimi, ale logika kateny, łańcucha, w której każde ogniwo jest istotne i niepomijane w drodze do prawdy. Próbując określić zadania tomizmu biblijnego, nie sposób nie zauważyć tej kwestii źródeł, z której płynie ważna wskazówka, jak dziś „uprawiać teologię po Tomaszowemu” (ad mentem Thomae) - albo lepiej: „razem z Tomaszem”. W sposobie, w jaki Tomasz pracuje na źródłach, ujawnia się jego najgłębsza metoda, która świadczy o wielkości jego myśli i nieprzemijającej nowości (FeR 43). Odtwarzanie teologii Akwinaty w abstrahowaniu od jego stosunku do auctoritas, do źródeł i skupianie się na wątku materialnym rozstrzygnięć narażone jest na ryzyko powtarzania bez zrozumienia ${ }^{12}$. W gruncie rzeczy chodzi o to, co hasłowo wyraził Remi Brague w określeniu konieczności powrotu do Tomasza we współczesnej kulturze teologicznej, formułując swój postulat jako zachętę do uprawiania teologii w duchu "Akwinata Aquinans, non Aquinatum". Nie petryfikowanie rozwiązań z przeszłości, lecz generowanie nowych, opartych na modelu rozumienia struktur globalnych, a więc właściwej Tomaszowi wrażliwości na rzeczywistość stworzenia i jego umiejętności syntezy całości doświadczeń, bez pozostawiania na marginesie pewnych wymiarów rzeczywistości.

12 Idem, Wokół konceptu auctoritas, s. 67-90. 
Dlatego istotne znaczenie $\mathrm{w}$ metodzie tomizmu biblijnego przypada egzegezie Ojców Kościoła, których głos jest nie tylko świadectwem przeszłości i dawnej interpretacji, lecz także zwróceniem uwagi na eklezjalność egzegezy średniowiecznej ${ }^{13}$. Dokonywała się ona w Kościele jako właściwej przestrzeni hermeneutycznej i dlatego rola Ojców Kościoła nie jest przywoływaniem betonowych bloków prawdy, lecz kontynuacją ich drogi (dlatego Ojcowie mogą pojawić się w videtur quod non, ale i sed contra). Wynika to $\mathrm{z}$ faktu, że średniowieczny egzegeta, taki jak Tomasz, jest przekonany o nieskończonych możliwościach interpretacji Słowa Bożego, którego poznawczo nie wyczerpie się nigdy. Jego natura jest nieskończona jak sam Bóg, który nadto nie mówi samym słowem, ale wydarzeniami całej historii zbawienia. Egzegeza byłaby więc rozładowywaniem potencjalności Słowa Bożego.

\section{Egzegeza secundum mysticum intellectum}

Tomasz jest przekonany, że Biblia nie jest księgą taką jak pozostałe, ponieważ nie zawiera tylko „słów”, ale i „czyny”. Bóg posługuje się zarówno słowami, jak i wydarzeniami, o których te słowa traktują. To, co wydarzyło się w historii i jest przekazywane za pomocą słowa natchnionego, otwiera możliwości interpretacji, które sprowadzają się do znaczenia literalnego i duchowego. To właśnie jeden z wyróżników średniowiecznej hermeneutyki, która historię traktuje w kategoriach uczestnictwa, a nie linearnie (Levering). Z takiego podejścia rodzi się Tomaszowa lektura Biblii, która jest holistyczna, oparta na modelu historii zbawienia, na pierwszeństwie „wydarzenia” nad „tekstem” (res nad annuntiabile), niezmierzająca do homogenicznej wizji, w której należy eliminować niepasujące elementy. Tomasz nie myśli o Biblii w kategoriach unisono, lecz dopuszcza wielość możliwych przekazów, na różnych poziomach. Jego ulubionym przekazem pozostaje symfoniczność, w której tę samą prawdę niejako oświetla się $\mathrm{z}$ wielu perspektyw, wybrzmiewa w wielu dźwiękach. Może dlatego nieustannie natrafiamy na vel, który jest czymś więcej niż spójnikiem otwierającym wielość interpretacji, ale czymś w rodzaju „znaku wodnego” jego egzegezy, ciągle nienasyconej i przekonanej, że duchowa wykładnia nie „kłóci” się z literalną, gdyż jest to odczytanie jednak uporządkowane, bazujące na znaczeniu dosłownym (jako fundamencie, in cortice litteralis sensus) i twórczo rozwijające bogate odniesienia duchowe. W tym względzie Tomasz kontynuuje wielkie tradycje szkoły św. Wiktora, która domagała się od egzegetów „szkolnych” swego czasu powrotu do tradycyjnego modelu harmonizującego sens dosłowny i duchowy:

13 L. Elders, Thomas d’Aquin (zwłaszcza rozdziały 7, 8 i 9). 
w przeciwnym razie, zbyt szybko przechodząc do spekulacji, niszczy się samo Pismo i naraża na błądzenie. Pokarm duchowy nie inaczej syci człowieka, jak tylko będąc wpierw zmielonym zębami, a św. Bonawentura doda, że duchowe treści można pisać jedynie alfabetem litery ${ }^{14}$.

W konsekwencji tomizm biblijny staje się inspiracją do wyeksponowania we właściwych proporcjach i odniesieniach zamiarów Tomasza, harmonijnego odczytywania Pisma secundum mysterium albo secundum mysticum intellectum, które jest możliwe we właściwej sekwencji. To nie są lektury wykluczające się. Jak już zauważyliśmy, Tomaszowa egzegeza to nieustanne zmienianie perspektywy, opcje alternatywnych odczytań (rzadko przy tym ocenianych, czy są dobre czy złe, choć zdarza się, że krótko Tomasz stwierdza, że dana interpretacja melior est), gdyż odczytanie mistyczne nie „zastępuje” dosłownego. Przykładem może być Wykład Psalmów, w którym wołanie o pomoc przeciw wrogom wyraża w sensie mistycznym wołanie samego Chrystusa ${ }^{15}$, albo werset "głos Pański ponad wodami / zagrzmiał Bóg majestatu” (Ps 29(28),3) jest nawiązaniem to tajemnicy wcielenia, skoro grzmoty związane są z chmurami, a te $\mathrm{w}$ języku biblijnym - w obrazie zstępowania $\mathrm{z}$ chmur - opowiadają o przychodzeniu Syna Człowieczego. Głos nad wodami w sensie mistycznym to wezwanie do nawrócenia, jakie słyszeli Żydzi w Starym Testamencie ${ }^{16}$. Podobnie w komentarzu do Mateusza, interpretując Mt 11, w którym Jezus posługuje się analogią do gry dzieci na placu, Akwinata zauważa, że obok prostego wyjaśnienia literalnego, nawiązującego ze względu na swój kontekst do postaci Jana Chrzciciela, możliwe jest również odczytanie „mistyczne”, osadzone w realiach Starego i Nowego Testamentu. Tomasz często pozostaje tu uczniem Ojców Kościoła, zwłaszcza św. Grzegorza Wielkiego.

Ogromną rolę w tej duchowej lekturze odgrywają procedury egzegetyczne Tomasza, które współczesnego czytelnika mogą dziwić. Jedną z nich, często pozostającą w służbie duchowej wykładni, jest przytaczanie, a wręcz zestawianie obok siebie kilku cytatów z innych ksiąg Pisma Świętego, które nie są prostą dokumentacją, potwierdzeniem słuszności interpretacji, ale swego rodzaju "Zwrotnicą”, kierującą na często zaskakujące tory ${ }^{17}$. Wzajemne „wołanie” do siebie cytatów ma służyć temu, aby osadzić czytelnika w nowym kontekście interpretacyjnym - jakby szukając lepszego światła potrzebnego do kontemplacji danej sceny biblijnej. Nawet pojawiające się co jakiś czas supple, dopowie-

14 H. de Lubac, Medieval Exegesis.

15 In Ps. 40, n. 4.

16 In Ps. 28, n. 5

17 Szerzej o tej procedurze i jej znaczeniu pisałem w: P. Roszak, The place and function, s. 115-139. 
dzenie, które ma ułatwić zrozumienie, domyślne założenie biblijnego zdania, pokazują uważny tryb lektury Pisma u Tomasza: „pług” egzegezy ma użyźnić pole poszukiwań hermeneutycznych i przygotować człowieka do kontemplacji, bo przecież finałem tej egzegetycznej drogi było nie tyle samozadowolenie odkrywcy, ile głębokie praedicatio, a więc proklamacja kerygmatu skutkująca przemianą życia.

Wszystkie te elementy stara się na różne sposoby wydobyć „tomizm biblijny"18. Służy temu również specyficzna logika „przedsmaku”" antycypacji, zapowiedzi, ale także pewna odporność na metafory, w które nie chce się zakuwać teologii, aby jej consummatio nie odbywała się na poziomie języka, ale obejmowała egzystencję człowieka. Oczywiście, metafory są obecnie w egzegetycznej praktyce Tomasza (to niezwykle ciekawy temat ostatnio szeroko zgłębiany m.in. przez O.Th. Venarda OP), ale są przekraczane, bo ze swej natury pomagają lepiej uchwycić tak właściwe dla języka teologicznego „niedomówienie". To nie celowe unikanie ścisłości, lecz świadomość kontemplacyjnego stawania w obliczu rzeczywiści zawsze większej, wymykającej się próbie wyczerpującego opisu. Dlatego choć formułowana w rygorze naukowej ekspresji, daleko od epatujących emocjami sformułowań, egzegeza Tomasza to ćwiczenie czytelnika w postawie pochwalnej, doksologicznej wobec Stwórcy: postawa, która została w pewnej mierze utracona przez Adama w raju wedle opisu biblijnego.

Celem tomizmu biblijnego wydaje się, że jest właśnie chęć niepomijania żadnego momentu w praxis teologicznej, niechodzenia na skróty, ale kumulującego głosu uwielbienia wobec Stwórcy, który działa w stworzeniu i historii świata. Tomizm biblijny jest w tym wymiarze mistagogiczny, bo zwrócony ku prowadzeniu - istota mistagogii jako kroczenia razem w tym samym kierunku, choć obok siebie, nie jeden „za” drugiego - w stronę deiformitas.

\section{Co znajdziemy ważnego w komentarzach, czego nie ma w Sumie teologii?}

Komentarze biblijne nie stanowią wyizolowanego obszaru aktywności uniwersyteckiej Tomasza ani nie są dziełem epizodycznym, ale głęboko powiązanym z innymi formami ekspresji jego teologicznej myśli, zapewne najbardziej dojrzałej i oryginalnej, jakimi są dzieła systematyczne, zwłaszcza Suma teologii. 
Z jednej strony pozostaje oczywiste, że głębokie przemyślenie interpretacji pewnych fragmentów Pisma Świętego przez Tomasza prowadziło do zmian w sposobie podejścia do konkretnych kwestii teologicznych. Dlatego jego komentarze biblijne odgrywają doniosłe znaczenie dla zrozumienia Tomasza i drogi rozwoju jego myśli - co niestety nie zawsze się dostrzega, traktując ją jako monolit, w którym nie ma wewnętrznego dojrzewania pewnych idei. Tomaszowa teologia rozwija się również dzięki głębszemu wnikaniu w pewne fragmenty Pisma, które jak pokazują analizy na bazie Corpus Thomisticum zaczynają w pewnych okresach jego życia odgrywać ważniejsze znaczenie, co widać w częstotliwości nawiązań do nich. Tak jest choćby, jak zauważa Daria Spezzano w ciekawym studium nt. koncepcji ubóstwienia u Tomasza, $\mathrm{z}$ fragmentem 2 P 1,4 (Przez nie zostały nam udzielone drogocenne i największe obietnice, abyście się przez nie stali uczestnikami Boskiej natury - BT), który postrzega łaskę w kategoriach „uczestnictwa w boskiej naturze”: wyraźnie staje się bardziej obecny w dojrzałych pismach Tomasza ${ }^{20}$. Więcej, widać wyraźnie, że w pewnych okresach życia Tomasza bardziej eksponuje on pierwszy (wielkość obietnic danych człowiekowi w Chrystusie), a innym razem drugi człon cytatu (skutki tych obietnic - uczestnictwo w naturze Bożej). Oznacza to, że obcowanie z Pismem, które wiązało się z realizacją obowiązków akademickich - biblijnej lectio, a także praedicatio - otwierało przed Akwinatą całą serię kwestii teologicznych wpisanych w syntezę dogmatyczną. Cytaty nie są więc jedynie ozdobnikami i dokumentacją argumentacyjną, ale śladem' genezy myśli Akwinaty i warto w podejmowanych studiach nad poszczególnymi aspektami myśli zwracać na to uwagę.

$\mathrm{Z}$ drugiej strony to Suma pozwala lepiej zrozumieć komentarze, a nie tylko odwrotnie! Trzeba pamiętać o równoległych torach pracy nad komentarzami i dziełami systematycznymi w życiu Tomasza, jak to było, gdy choćby w Orvieto wyjaśniał księgę Hioba, pracując jednocześnie nad trzecią księgą Summa Contra Gentiles i przygotowując się do Secunda Pars Sumy teologii. Podobnie było z lekturą Listu św. Pawła do Rzymian i opracowywanym traktatem o ła$\mathrm{sce}^{21}$. Komentarze kontrastują Tomasza ze źródłami i kanalizują spekulatywne impulsy, dlatego teologiczna spekulacja w Sumie to owoc przejścia myśli przez Słowo, a ten pryzmat dopiero potem się rozszczepia na poszczególne wnioski teologiczne. W sed contra pojawiają się cytaty, których Tomasz nie rozwija i dla rekonstrukcji jego myśli i zrozumienia „siły” argumentu konieczne jest wrócenie do komentarzy i zrozumienie całego kontekstu myśli. Komentarze odsła-

20 D. Spezzano, The Glory of God's, s. 153.

21 S.M. Colberg, Aquinas and the Grace, s. 187-210. 
niają priorytet i pierwszeństwo Objawienia w teologicznym namyśle, ale także miejsce refleksji filozoficznej, która komponuje się w harmonijnej syntezie.

$\mathrm{Z}$ tego powodu synteza dogmatyczna Tomasza choćby z Sumy teologii jest niezrozumiała bez jego rozumienia Pisma w nurcie Tradycji, co wyrażają jego komentarze będące przejawem lektury eklezjalnej Biblii. Wiele razy Akwinata opiera swe wywody nie tylko na cytatach, ale odwołaniach do innych komentujących Pismo, najczęściej Ojców Kościoła, którzy przed nim pochylali się nad tekstem biblijnym. Tomasz nie pomija ich w swojej interpretacji, ale jednocześnie nie plącze się w gąszczu nawiązań. Jego egzegeza pozostaje optymistyczna i otwarta, nie ucina interpretacji odwołaniem do Magisterium, wręcz przeciwnie: proponuje równolegle kilka możliwych wariantów interpretacyjnych. Warto również zauważyć, że Tomasz nie pisze swoich komentarzy ze względu na późniejsze publikacje - tak jest w przypadku komentarza do Psalmów, jak zauważa M. Morard, będącego raczej próbką jego codziennych wykładów prowadzonych w ściśle określonym środowisku.

Próbując ustalić wartość komentarzy dla pełnego uchwycenia myśli Akwinaty, nie należy myśleć o ich powiązaniach z dziełami systematycznymi na zasadzie część-część. Nie chodzi bowiem o „materialne” uzupełnienia, jakie mogłyby się znajdować w jednych czy drugich dziełach, lecz o rekonstrukcję swoistego „łańcucha myśli” (catena!), który wyrasta z Biblii. Jego odtworzenie jest kluczowe dla pełnego zrozumienia idei Akwinaty. Nie można z wielkiego gmachu wyjmować cegły za cegłą, bo grozi to zawaleniem. Nie chodzi więc o to, czego "nie ma” w komentarzach czy Sumie, lecz widzenie dwojgiem oczu, rekonstrukcję Tomaszowej drogi teologicznej, bo dla tomizmu biblijnego to właśnie pozostaje kluczową sprawą. Powiązanie na trwałe egzegezy i teologii spekulatywnej, ale nicią trwałej wspólnoty korzenia skrypturystycznego.

Gadamer, pisząc o zadaniach hermeneutyki, widział ją jako budzenie słowa uwięzionego, znieruchomiałego w piśmie. Wydaje się, że jest to bliskie także Tomaszowej idei zadań egzegezy (i rodzącej się z/w niej teologii - sacra doctrina), która jest w gruncie rzeczy kontemplacją obecnej w historii convenientia działania Boga i odkrywanie, że Słowo nie jest martwym zapisem, lecz potencjalnością niemożliwą do całkowitego wyczerpania interpretacyjnego. Teologia jawi się w ten sposób w swym pedagogicznym charakterze jako nauczająca w jaki sposób odpowiadać na samo-objawienie się Boga, którego świadectwem jest Pismo Święte ${ }^{22}$.

22 O relacji między Objawieniem a Pismem Świętym u Tomasza z Akwinu por. P. Roszak, Revelation and scripture, s. 191-218. 


\section{Filozoficzna free-zone w komentarzach?}

Tomasz pozostaje sobą również w swoich komentarzach. Nie odseparował się w nich od swoich filozoficznych założeń, ale pozostaje mistrzem syntezy, w duchu swojej wizji teologii, która nie zamyka się w getcie, ale buduje spójną wizję uwzględniającą osiągnięcia nauk swego czasu i chrześcijańskie Objawienie. To systemowość „otwarta”, która nie zamyka Biblii w jednym ze światów, a refleksji systematycznej $\mathrm{w}$ drugim. Z pewnością dziś oczekiwania wobec komentarzy biblijnych są często inne: istnieje preferencja, aby nie włączać do ekslipkacji narzędzi pojęciowych pózniejszych od czasów Pisma (np. metafizycznych), ale trzymać się jedynie świata biblijnego, jego konceptów i horyzontu poznawczego, aby nie narazić sie na ahistoryczność interpretacji. Bez wątpienia przemawia za takim rozumieniem, jak widział to Ricoeur, postrzeganie Pisma w sepracji od wspólnoty hermeneutycznej, jako swoistą - by użyć jego metafory - „sekcję zwłok”, która ma uchwycić fenomen chwili. Ale rozumienie Tomasza jest tu inne: Słowo Pisma nie jest przekazem na jedno pokolenie i nie może być czytane w oderwaniu od innej księgi, liber naturae. To żywe Słowo, które zmienia czytającego, niewyczerpane w swej mocy.

$\mathrm{W}$ tomizmie biblijnym nie chodzi więc o biblicyzm, przesycenie filozofii biblijnym słownictwem, lecz odczytanie przesłania tekstu biblijnego (sententia), który nie może stać w sprzeczności z rozumowym poszukiwaniem prawdy. To sententia jest zwieńczeniem poszukiwania sensu dosłownego, nie zaś samo odczytanie tekstu (littera) i kontekstu (sensus) - najpełniejszym jej wyrazem jest sens dosłowny Nowego Testamentu, który ukazuje całościowe odczytanie historii zbawienia (stąd twierdzenie Tomasza, że pewne Psalmy traktują o Chrystusie w sposób literalny).

Filozoficzne tematy często pojawiają się w Tomaszowych komentarzach w różnej formie. Z jednej strony to 'noty' (notae) i 'kwestie' (quaestiones), które wtrąca średniowieczny egzegeta, krytycznie czytając tekst Pisma. Widzimy Tomasza, który prowadzi nawet krytykę narracyjną, dostrzegając niespójności (choćby chronologiczne) w narracji tekstu i je wyjaśnia ${ }^{23}$. To pokazuje, że Tomasz czyta Biblię w sposób „uważny” i prowadzi z nią dialog, w którym jest czas pytań i eksploracji odpowiedzi. Przypomina to spuszczanie sondy pod ziemię, a Akwinata wydaje się niezaspokojony aż jego rozumienie Słowa będzie na właściwym, głębokim poziomie, uwzględniające szereg zagadnień szczegółowych. Pozostaje w tym jednak mistrzem równowagi, który w przeciwieństwie do swoich średniowiecznych rówieśników, nie traci z pola widzenia najważ-

23 G. Dahan, La méthode critique, s. 118-124. 
niejszych wątków. To one organizują jego wykład - wielka tu rola divisio textus będącego kręgosłupem czy nicią przewodnią właściwego porządku wyjaśniania. To coś więcej niż organizacja tematu - to wskazówka i klucz do lektury całego komentarza.

Jak zwrócił uwagę T. Bellamah OP, filozoficzne rozstrzygnięcia pozostają widoczne $w$ innych jeszcze obszarach egzegezy średniowiecznej. Rozumienie i podział na pierwszą przyczynę oraz przyczyny drugorzędne miało niezwykle doniosłe znaczenie dla scholastycznego rozumienia kwestii autorstwa Pisma Świętego. Ważną rolę odegrała tu Liber de causis i zawarta w niej nauka ${ }^{24}$. Widać wyraźnie, jak w poszukiwaniach dokonujących się w ramach sacra doctrina spotyka się cały dorobek wiedzy ówczesnego czasu.

\section{Apologia prostoty. Na czym polega prawdziwa simplicitas?}

Gdy Tomasz komentuje List do Efezjan, w ostatnim rozdziale zwraca uwage na zalecaną przez św. Pawła postawę prostoty serca w relacjach, które odczytać dziś możemy jako odnoszące się do relacji przełożony-podwładny (oczywiście Tomasz posługuje się kategoriami swojej epoki, które nie powinny nas zmylić). Przykładem takiej prostoty jest Hiob - vir simplex, na którego wskazuje Tomasz nie w toku eksplikacji głównej myśli, lecz przez swą technikę cytacji ${ }^{25}$. Warto na zakończenie naszych refleksji prześledzić, w myśl założeń tomizmu biblijnego, to sprzężenie obu, zarówno egzegezy, jak i teologii spekulatywnej.

Jednakże postawę prosty serca (simplicitas cordis) wywołaną w komentarzu do Efezjan warto odczytać w perspektywie przemyśleń Tomasza z Sumy teologii, gdy zgłębia prostotę jako przymiot Boga ${ }^{26}$. Mogłoby się wydawać to mało ze sobą powiązane, a jednak to właśnie tę drogę zdaje się sugerować Tomasz i dlatego kluczem interpretacyjnym jest tutaj cytat z 2 Kor 11,3, w którym mowa

24 T. Bellamah, Tunc scimus cum, s. 154-172.

25 In Eph., cap. VI, lect. 2: „...oraz $w$ prostocie serca. Mdr 1,1: w prostocie serca szukajcie Go. Łk 12,42: wierny sługa etc. Hi 1,8: czyż zwróciłeś uwagę na sługę mego Hioba, etc., i trochę później: mąż prosty, etc.", tłum. własne

26 Tomasz nawiązuje wprost do tej zależności choćby w In 1 Tim, cap. VI, lect. 2, gdzie stwierdza: „Doskonałość człowieka polega bowiem na tym, że jego serce koncentruje się na jednym, gdyż im coś staje się bardziej jednością, tym bardziej upodabnia się do Boga, który jest prawdziwą jednością". Ps 27 (26)4: O jedno prosiłem Pana itd. Coś przeciwnego dotyka szukającego bogactwa, ponieważ jego serce skłania się ku różnym rzeczom. Oz 10, 2: Ich serce podzielone, zginie. I dlatego to [jest napisane] w Mt 6, 21: Gdzie jest skarb wasz, [tam będzie i serce wasze]", tłum. o. M. Hanusek OP. 
o „prostocie Chrystusa”27. Chodzi o czystą pobożność, całkowicie oddaną woli Ojca, która przebija z postawy i czynów Jezusa: On uczy tego, co sam pokazuje. Ta prostota - której obrazem jest gołębica, nieprzypadkowo zdaniem Tomasza pojawiająca się w scenie chrztu Chrystusa w Jordanie - to wskazanie na troskę o niepodzielność serca, aby nie dochodziło do rozdźwięku między prawdami wyznawanymi ustami a postępowaniem. To jednocześnie objawia dzieło dokonywane przez Ducha Świętego w życiu chrześcijanina: prostota serca odnosi się więc do pełnego ukierunkowania woli na Boga, które skutkuje prawdziwym pokojem. Obok jednak tego negatywnego wydźwięku simplicitas, która ma nie dozwolić na to, aby serce człowieka zostało owładnięte przez dwóch „panów”, a więc jako postawy przeciwnej „przebiegłości”28, mamy również pozytywne wskazania co do prostoty, którą poszerza rozważanie na temat 'dobroci' i stabilności trwania w dobru. Temu wszystkiemu sprzyjają refleksje o prostocie Boga i jej relacji do Jego działania: wola Boża nie jest zdeterminowana niczym innym jak swoją dobrocią 29 . A jednocześnie simplicitas kieruje myśli ku jedności Boga, będącej puntem odniesienia dla jedności życiowego projektu człowieka (również w jego wymiarze eschatologicznym) oraz zachowywania jedności w Kościele dzięki miłości owocującej pokojem. W jedności Boga uczestniczymy bowiem jako stworzenia zarówno w sensie jednostkowym, jak i wspólnotowym. To kolejne rysy moralnej nauki, od której nie stroni tomizm biblijny, o czym świadczą publikacje jego głównych przedstawicieli.

Metafizyczne poszukiwania Tomasza znajdują swoje powiązanie w etyczno-moralnych rozważaniach, a refleksja stricte dogmatyczna o Bogu znajduje przełożenie na sposób życia chrześcijańskiego. W epoce podziałów i segmentyzacji teologii, często okopanej na swoich metodologicznych granicach, propozycja tomizmu biblijnego wydaje się trafną receptą na odzyskanie i przedstawiania w pełnym świetle zamysłu Tomasza. To zadanie, które staje obecnie przy badaniach nad myślą Akwinaty. Warto zwracać uwagę na obecność cytacji biblijnych w strukturze argumentacyjnej Akwinaty, ich odczytywanie przez Tomasza, a z drugiej strony na umiejętność osadzania na szerokiej perspektywie mistagogicznej, w której to, w co wierzę, znajduje swój wyraz w tym, jak żyję.

27 T.R. Wittman, Not a God, s. 151-169. W opisie simplicitas opieram się na wskazanych w tym artykule wątkach.

28 In 1 Cor., cap. XIV, lect. 4.

29 T.R. Wittman, Not a God, s. 163: „....insofar as his people imitate the divine simplicity, inspired by the Holy Spirit and taught by Christ and his single-minded devotion to God, they acquire a corresponding determination that is at once innocent and peaceful". 


\section{Bibliografia}

Alarcón, E., El tomismo contemporáneo: datos para una nueva interpretación del presente w: C.A. Casanova, I. Serrano del Pozo (eds.), Gratia non tollit naturam sed perficit eam. Sobre las relaciones y límites entre naturaleza y gracia, RIL, Santiago de Chile 2016, s. 25-32.

Bellamah, T., Tunc scimus cum causas cognoscimus: Some Medieval Endeavors to Know Scripture in Its Causes, w: M. Lamb (red.), Theology Needs Philosophy. Acting Against Reason is Contrary to the Nature of God, The Catholic University of America Press, Washington 2016, s. 154-172.

Berkman, J., Steven Titus, C. (eds.), The Pinckaers Reader: Renewing Thomistic Moral Theology, CUA Press, Washington 2005.

Bonino, S.Th., To be a thomist, Nova et Vetera (English Edition), 4 (2010), s. 763-773.

Canellis, A., Jerome's hermeneutics: how to exegete the Bible?, w: T. Toom, Patristic Theories of Biblical Interpretation. The Latin Fathers, CUP, Cambridge 2016, s. 49-76.

Colberg, S.M., Aquinas and the Grace of Auxilium, Modern Theology 2 (2016), s. 187-210 .

Dahan, G., La méthode critique dans l'étude de la Bible (XIIe-XIIIe siècles), w: M. Chazan, G. Dahan (eds.), Le méthode critique au Moyen Age, Brepols, Turnhout 2006, s. 118-124.

Dahan, G., Thomas Aquinas: Exegesis and Hermeneutics, w: P. Roszak, J. Vijgen (red.), Reading Sacred Scripture with Thomas Aquinas. Hermeneutical tools, theological questions and new perspectives, Brepols, Turnhout 2015, s. 45-70.

DiNoia, J.A., Thomism After Thomism: Aquinas and the Future of Theology, w: D.W. Hudson, D. Wm. Moran (eds), The Future of Thomism, University of Notre Dame Press, Notre Dame 1992, s. 231-245.

Elders, L., Thomas d'Aquin et ses prédécesseurs. La présence des grands philosophes et Pères de l'Église dans les oeuvres de Thomas d'Aquin, Les Presses universitaires de l'IPC, Paris 2015.

Haldane, J., Thomism and the Future of Catholic Philosophy, New Blackfriars 80 (1999), s. $158-169$.

Hütter, R., Levering, M. (eds.), Ressourcement thomism. Sacred Doctrine, the Sacraments, and the Moral Life, CUA Press, Washington 2010.

Levering, M., Pismo Święte i metafizyka. Tomasz z Akwinu i odnowa teologii trynitarnej, Dominikańskie Studium Filozofii i Teologii, Kraków 2016.

Lubac, H., Medieval Exegesis, vol. 3, T\&T Clark, Edinburgh 2009.

Rosemann, Ph., What is an Author? Divine and Human Authorship in Some Mid-Thirteenth-Century Commentaries on the Book of Sentence, Archa Verbi 12 (2015), s. 35-64.

Roszak, P., Biblia i metafizyka: ku tomizmowi biblijnemu, w: Tomasz z Akwinu, Wykład Listu do Kolosan, Super Epistolam B. Pauli ad Colossenses lectura, Wydawnictwo Naukowe UMK, Toruń 2012, s. 9-21. 
Roszak, P., Revelation and scripture: exploring the Scriptural Foundations of sacra doctrina in Aquinas, Angelicum 93 (2016), s. 191-218.

Roszak, P., The place and function of biblical citation in Thomas Aquinas' exegesis, w: P. Roszak, J. Vijgen (ed.), Reading sacred scripture with Thomas Aquinas. Hermeneutical tools, theological questions and new perspectives, Brepols, Turnhout 2015, s. 115-139.

Roszak, P., Wokół konceptu auctoritas w teologii św. Tomasza z Akwinu, Człowiek w Kulturze 22 (2011/2012), s. 67-90.

Rowland, T., Culture and the Thomist Tradition. After Vatican II, Routledge, London-New York 2003.

Rowland, T., Ratzinger's Faith: The Theology of Pope Benedict XVI, Oxford University Press, Oxford and New York 2008.

Spezzano, D., The Glory of God's Grace. Deification according to St. Thomas Aquinas, Sapientia Press, Ave Maria FL 2015.

Wittman, T.R., Not a God of Confusion but of Peace': Aquinas and the Meaning of Divine Simplicity, Modern Theology 2 (2016), s. 151-169. 